\title{
New Silver Complexes with Mixed Thiazolidine and Phosphine Ligands as Highly Potent Antimalarial and Anticancer Agents
}

\author{
Nur Rahimah Fitrah Mohd Sofyan, ${ }^{1}$ Fariza Juliana Nordin, \\ Mohd Ridzuan Mohd Abd Razak, 'Syahrina Nur 'Ain Abdul Halim,' \\ Nur Adila Fatin Mohd Khir, ${ }^{1}$ Amirrudin Muhammad, ${ }^{3}$ Nor Fadilah Rajab, \\ and Rozie Sarip ${ }^{1}{ }^{1}$ \\ ${ }^{1}$ Department of Chemistry, Faculty of Science, University of Malaya, Lembah Pantai, 50603 Kuala Lumpur, Malaysia \\ ${ }^{2}$ Faculty of Health Sciences, Universiti Kebangsaan Malaysia, Kuala Lumpur Campus, Jalan Raja Muda Abdul Aziz, \\ 50300 Kuala Lumpur, Malaysia \\ ${ }^{3}$ Bioassay Unit, Herbal Medicine Research Centre, Institute for Medical Research, Jalan Pahang, 50588 Kuala Lumpur, Malaysia
}

Correspondence should be addressed to Rozie Sarip; rozie@um.edu.my

Received 6 March 2018; Revised 1 June 2018; Accepted 14 June 2018; Published 16 July 2018

Academic Editor: Kokhwa Lim

Copyright $\odot 2018$ Nur Rahimah Fitrah Mohd Sofyan et al. This is an open access article distributed under the Creative Commons Attribution License, which permits unrestricted use, distribution, and reproduction in any medium, provided the original work is properly cited.

\begin{abstract}
Five silver(I) complexes containing a mixed ligand system of phosphine and thiazolidine were successfully synthesized. The structural information of the complexes was assembled using various spectroscopic techniques such as CHN elemental analysis, Fourier transformed infrared (FTIR), ${ }^{1} \mathrm{H},{ }^{13} \mathrm{C}$, and ${ }^{31} \mathrm{P}\left\{{ }^{1} \mathrm{H}\right\}$ NMR spectroscopy, and thermogravimetric analysis (TGA). A bidentate phosphine ligand acted as a chelating agent which bond to the silver in $1: 2$ molar ratios. Meanwhile, thiazolidine was attached to the silver in a 1:1 molar ratio. The antiplasmodial properties of all synthesized complexes were investigated on chloroquine-resistant $P$. falciparum parasite via HRP2 assays and cytotoxicity tests on Vero cells. Of all the synthesized complexes, complex 2 showed the highest SI value (more than 12.4) followed by complex 5 (6.6). The potent properties of compounds 2 and 5 were also noted in the in vitro antiproliferative assays involving MDA-MB-231 and MCF-7 breast cancer cell lines as well as HT-29 colon cancer cell line. Complex 2 was selective for MDA-MB-231 cells $\left(\mathrm{GI}_{50}=1.9 \pm 0.3 \mu \mathrm{M}\right)$, while complex 5 acted predominantly on breast carcinoma cells $\left(\mathrm{GI}_{50} \mathrm{MDA}-\mathrm{MB}-231=4.7 \pm 1.1 \mu \mathrm{M}\right.$; MCF-7 $\left.=2.9 \pm 0.9 \mu \mathrm{M}\right)$ instead of colon carcinoma (HT-29) cells $\left(\mathrm{GI}_{50}=15.1 \pm 1.9 \mu \mathrm{M}\right)$.
\end{abstract}

\section{Introduction}

Over the years, the synthesis of complexes with transition metals and mixed ligand that offers few points of donating ability has attracted much attention due to their special structures [1-3], catalytic abilities [4,5], and especially their potential applications in biomedical field [6]. In particular, silver(I) complexes containing mono- or bidentate phosphine ligands and thiol or thione moieties have wellestablished applications in the form of anticancer $[7,8]$ and antimalarial $[9,10]$ agents. Numerous ligands derived from mono- and diphosphines have been explored for their ability to coordinate with silver, hence enabling their development as antiproliferative agents [11]. Thiazolidine is one of the compounds which show good potential in various biological activities $[12,13]$. Based on the analyses and databases from the National Cancer Institute (NCI, USA), approximately about 42,247 compounds which consist of 734 nonfused and 146 fused thiazolidine derivatives are active in three tumor cell line assays. On the contrary, malaria is a parasitic disease that occurs predominantly in tropical countries. In 2015 alone, 212 million malaria cases have been reported worldwide [14]. An increasing number of research on the application of silver(I) complexes has been conducted as the complexes are a leading candidate for the curing of various infectious diseases $[15,16]$. 
The development of a new metallotherapeutic drug containing silver coordination compound provides many benefits to human body because of its low toxicity [17]. Although cisplatin has a high cure rate, its uses are limited owing to side effects and toxicity issues $[18,19]$. On the contrary, the commercial antimalarial drug chloroquine showed some degree of ineffectiveness in light of parasite resistance [20]. As such, to overcome the limitations of cisplatin and chloroquine, we studied another form of metalbased drug which was less harmful and more effective by using silver complexes with a mixed ligand system of bioactive thiazolidine and phosphine. Even though malaria and cancer are totally different diseases with different symptoms, it is surprisingly possible to cure both diseases using the same drug since they have similar pathophysiology and mechanistic treatment pathway [21, 22]. Based on recent researches, there are also a number of anticancer drugs that display potent antimalarial properties [23]. Hence, we attempted to uncover compounds that can fulfil both roles, as an anticancer and antimalaria agent. In this research, we report the preparation of the silver(I) complexes with thiazolidine and different phosphine ligands along with their in vitro antiplasmodial and antiproliferative activities.

\section{Materials and Methods}

2.1. Experimental and Instrumentation. All the solvents and reagents were of analytical grade and purchased commercially from Sigma-Aldrich Ltd. The silver nitrate and 1,2-bis(diphenylphosphino)methane (dppm), 1,1-bis(diphenylphosphino) ethane (dppe), 1,1-bis(diphenylphosphino)ferrocene (dppf), triphenylphosphine $\left(\mathrm{PPh}_{3}\right)$, tri(o-tolyl)phosphine, ethanol, methanol, and acetonitrile were used as supplied without further purification unless stated otherwise. The $\mathrm{CHN}$ analyses were performed by PerkinElmer CHNS/O 2400 Series II. The infrared (IR) spectra were determined using a PerkinElmer Spectrum One FT-IR spectrophotometer (ATR) at a frequency range $450-4000 \mathrm{~cm}^{-1}$. JEOL FT-NMR ECX 400 (ECX 400) was employed to measure the NMR spectra of ${ }^{1} \mathrm{H},{ }^{13} \mathrm{C}$, and ${ }^{31} \mathrm{P}\left\{{ }^{1} \mathrm{H}\right\}$ at $400 \mathrm{MHz}$ in deuterated solvents without internal reference. The presence of metals and other elements was detected by energy-dispersive X-ray spectroscopy (EDX), powder X-ray diffraction (PXRD) was recorded on an X-ray diffractometer (PANalytical, Netherlands) with $\mathrm{Cu} \mathrm{Ka}$ characteristic radiation (wavelength $\lambda=0.154 \mathrm{~nm}$ ) at the voltage of $40 \mathrm{kV}$ and current of $40 \mathrm{~mA}$, the scanning rate was $4.25^{\circ} / \mathrm{min}$, and the scanning scope of $2 \theta$ was from 0 to $90^{\circ}$ at room temperature $\left(25^{\circ} \mathrm{C}\right)$, while the thermogravimetric analysis were carried out on a PerkinElmer TGA 4000 thermogravimetric analyzer at a heating rate of $10^{\circ} \mathrm{C} / \mathrm{min}$

2.1.1. Synthesis of 3-Benzyl-1,3-thiazolidine-2-thione. The thiazolidine ligand was synthesized in accordance to a method reported in the literature, with slight modifications [24]. Generally, benzylaminoethanol $(10 \mathrm{mmol}$, $1.4 \mathrm{~mL}$ ) was added dropwise into a solution of potassium hydroxide (50 mmol, $2.81 \mathrm{mg}$ ) in ethanol $(50 \mathrm{~mL})$. A clear solution was formed. Carbon disulfide $(50 \mathrm{mmol}, 3 \mathrm{~mL}$ )

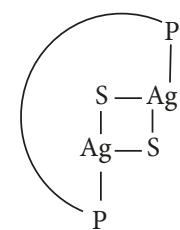

1,2 , or 3
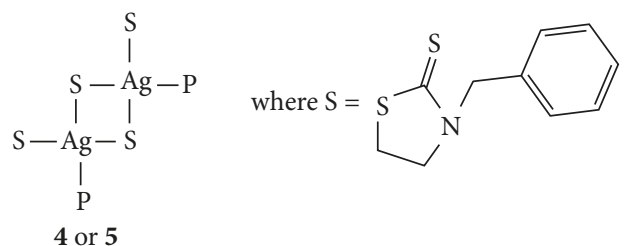

FIGURE 1: Proposed structure of silver complexes-corresponding P-ligand as listed in Table 1.

was added dropwise to the reaction mixture and then refluxed $\left(90^{\circ} \mathrm{C}\right)$ for $18 \mathrm{~h}$, resulting in an orange precipitate. This precipitate was filtered out and left to dry in an oven overnight.

Yield, $88 \%$, m.p. $132-133^{\circ} \mathrm{C}$. Anal. Calc. for $\mathrm{C}_{10} \mathrm{H}_{11} \mathrm{NS}_{2}$ : C, 57.38; H, 5.30; N, 6.69; and S, 30.64. Found: C, 57.06; H, 4.96; N, 6.34; and S, 30.61. IR: v(C-N) 1149 and $\mathrm{v}(\mathrm{C}=\mathrm{S}) 1242$. ${ }^{1} \mathrm{H}$ NMR (ppm, $\left.\mathrm{CD}_{3} \mathrm{CN}\right): 7.37-7.25(m, 5.41 \mathrm{H}, \mathrm{Ar}-\mathrm{H}) ; 4.93$ $\left(s, 2.07 \mathrm{H}, \mathrm{N}-\mathrm{CH}_{2}\right) ; 3.95\left(t, 2.01 \mathrm{H}, \mathrm{N}-\mathrm{CH}_{2}\right)$; and $3.23(t, 2 \mathrm{H}$, $\left.\mathrm{S}-\mathrm{CH}_{2}\right) \cdot{ }^{13} \mathrm{C}$ NMR $\left(400 \mathrm{MHz}, \mathrm{CD}_{3} \mathrm{CN}, \delta \mathrm{ppm}\right): 196.9(\mathrm{C}=\mathrm{S})$; 135-127 (4C, C-Ar); 56.3 (C-N); $51.9(\mathrm{C}-\mathrm{N})$; and 26.8 (C-S).

2.2. Synthesis of Silver Complexes. The complexes were prepared in accordance with the previously reported procedure [25] with slight modifications (Figure 1; Table 1). Different mono- and bidentate phosphines were utilized. For the bidentate phosphine, a suspension of silver nitrate $(2.00 \mathrm{mmol}, 0.17 \mathrm{mg}$ ) and bis-(diphenylphosphino)methane (1.00 mmol, $\quad 0.19 \mathrm{mg}), \quad$ 1,2-bis(diphenylphosphino)ethane $(1.00 \mathrm{mmol}, 0.20 \mathrm{mg})$, or 1,1 -bis(diphenylphosphino)ferrocene $(1 \mathrm{mmol}, 0.50 \mathrm{mg})$ in acetonitrile $(10 \mathrm{~mL})$ was stirred at $40^{\circ} \mathrm{C}$. A solution of 3-benzyl-thiazolidine-2-thione $(2 \mathrm{mmol}$, $0.21 \mathrm{mg})$ in methanol $(10 \mathrm{~mL})$ was then added. The resulting solution was filtered, and the clear solution was reduced to dryness.

While for monodentate phosphine [26], a solution of silver nitrate $(0.14 \mathrm{mmol}, 0.02 \mathrm{mg})$ in acetonitrile $(10 \mathrm{~mL})$ was added to a solution of 3-benzyl-thiazolidine-2-thione $(0.28 \mathrm{mmol}, 0.06 \mathrm{mg})$ in methanol $(10 \mathrm{~mL})$ followed by stirring at room temperature for $4 \mathrm{~h}$. Then, a solution of triphenylphosphine $(0.14 \mathrm{mmol}, 0.04 \mathrm{mg})$ or $\operatorname{tri}(o$-tolyl $)$ phosphine $(0.14 \mathrm{mmol}, 0.04 \mathrm{mg})$ in acetonitrile $(5 \mathrm{~mL})$ and methanol $(5 \mathrm{~mL})$ was added. The resulting solution was then filtered and reduced to dryness.

2.2.1. $\left[\mathrm{Ag}_{2}(\mathrm{dppm})\left(3-\right.\right.$ benzyl-1,3-thiazolidine-2-thione) $\left.{ }_{2}\right]$. $\left(\mathrm{NO}_{3}\right)_{2}$, 1. Yield, $54 \%$, m.p. $190-191^{\circ} \mathrm{C}$. Anal. Calc: C, 54.56 ; $\mathrm{H}, 4.24 ; \mathrm{N}, 2.36$, and $\mathrm{S} ; 10.79$ Found: C, 54.24; H, 3.92; N, 2.24, and S; 10.43. IR data $\left(\mathrm{cm}^{-1}\right): \vee\left(\mathrm{NO}_{3}{ }^{-}\right) 1310, \mathrm{~V}(\mathrm{C}-\mathrm{N})$ $1223, \mathrm{v}(\mathrm{C}=\mathrm{S}) 1152$, and $\mathrm{v}\left(\mathrm{P}-\mathrm{C}_{\mathrm{ph}}\right) 1094 .{ }^{1} \mathrm{H}$ NMR $(400 \mathrm{MHz}$, $\left.\mathrm{CD}_{3} \mathrm{CN}, \delta \mathrm{ppm}\right): 7.50-7.18(\mathrm{~m}, 30 \mathrm{H}, \mathrm{Ar}-\mathrm{H}) ; 4.89(s, 4.00 \mathrm{H}$, $\left.\mathrm{N}-\mathrm{CH}_{2}\right) ; 3.91\left(t, 4.36 \mathrm{H}, J=8 \mathrm{~Hz}, \mathrm{~N}-\mathrm{CH}_{2}\right) ; 3.67(s, 2.09 \mathrm{H}$, $\left.\mathrm{CH}_{2}-\mathrm{P}\right)$; and $3.13\left(t, 4.24 \mathrm{H}, J=8 \mathrm{~Hz}, \mathrm{~S}-\mathrm{CH}_{2}\right) .{ }^{13} \mathrm{C}$ NMR $\left(400 \mathrm{MHz}, \mathrm{CD}_{3} \mathrm{CN}, \delta \mathrm{ppm}\right): 196.7(\mathrm{C}=\mathrm{S}) ; 136-128$ (8C, $\mathrm{Ar}-\mathrm{C}) ; 56.6(\mathrm{C}-\mathrm{N}) ; 52.3(\mathrm{C}-\mathrm{N}) ; 26.8(\mathrm{C}-\mathrm{S})$; and $25\left(\mathrm{CH}_{2}-\mathrm{P}\right)$.

${ }^{31} \mathrm{P}\left\{{ }^{1} \mathrm{H}\right\}$ NMR (400 MHz, $\left.\mathrm{CD}_{3} \mathrm{CN}, \delta \mathrm{ppm}\right): 5.2,8.0(\mathrm{~s})$ 
TABLE 1: The complexes with its phosphine ligand.

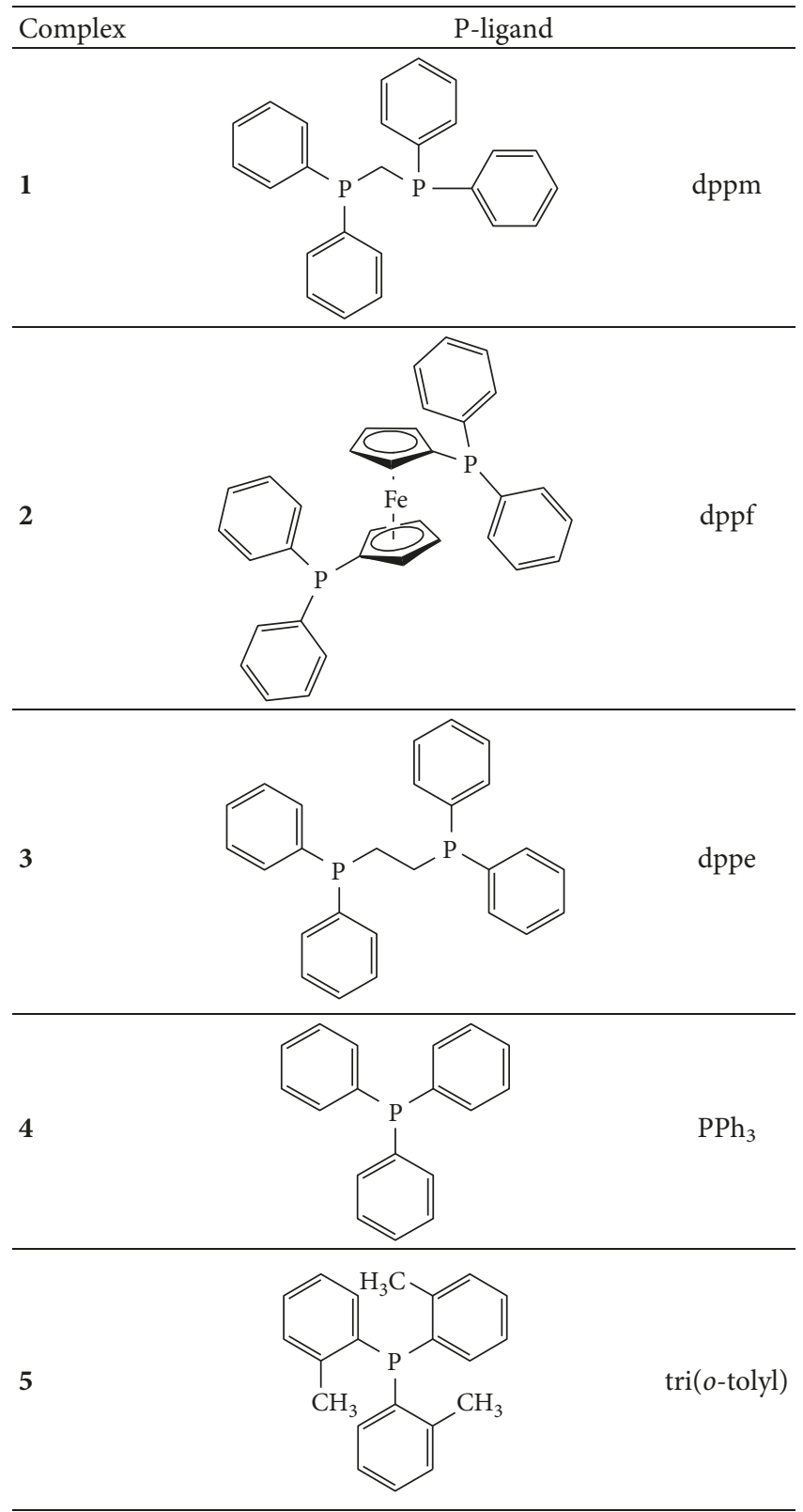

2.2.2. $\left[\mathrm{Ag}_{2}(\mathrm{dppf})(3-\text { benzyl-1,3-thiazolidine-2-thione })_{2}\right] \cdot\left(\mathrm{NO}_{3}\right)_{2}$, 2. Yield: $54 \%, \mathrm{Mp}: 190-191^{\circ} \mathrm{C}$. Anal. Calc: C, 54.56; H, 4.24; N, 2.36, and S; 10.79 Found: C, 54.24; H, 3.92; N, 2.24, and S; 10.43. IR data $\left(\mathrm{cm}^{-1}\right): \vee\left(\mathrm{NO}_{3}{ }^{-}\right) 1307, \mathrm{v}(\mathrm{C}-\mathrm{N}) 1223, \mathrm{v}(\mathrm{C}=\mathrm{S})$ 1163 , and $\mathrm{v}\left(\mathrm{P}-\mathrm{C}_{\mathrm{ph}}\right)$ 1095. ${ }^{1} \mathrm{H} \mathrm{NMR}\left(400 \mathrm{MHz}, \mathrm{CD}_{3} \mathrm{CN}\right.$, $\delta$ ppm): 7.50-7.28 (m, 30H, Ar-H); $4.93\left(s, 4.37 \mathrm{H}, \mathrm{N}-\mathrm{CH}_{2}\right)$; $4.35\left(s, 4 \mathrm{H}, \mathrm{C}_{5} \mathrm{H}_{4}\right) ; 4.17\left(s, 4.28 \mathrm{H}, \mathrm{C}_{5} \mathrm{H}_{4}\right) ; 3.95(t, 4 \mathrm{H}, J=8 \mathrm{~Hz}$, $\left.\mathrm{N}-\mathrm{CH}_{2}\right)$; and $3.11\left(t, 4.32 \mathrm{H}, J=8 \mathrm{~Hz}, \mathrm{~S}-\mathrm{CH}_{2}\right),{ }^{13} \mathrm{C} \mathrm{NMR}$ (400 MHz, $\left.\mathrm{CD}_{3} \mathrm{CN}, \delta \mathrm{ppm}\right): 197.1(\mathrm{C}=\mathrm{S}) ; 135-127$ (8C, ArC); $74\left(\mathrm{C}_{5} \mathrm{H}_{4}\right) ; 72\left(\mathrm{C}_{5} \mathrm{H}_{4}\right) ; 57.1(\mathrm{C}-\mathrm{N}) ; 52.5(\mathrm{C}-\mathrm{N})$; and 27.3 (C-S). ${ }^{31} \mathrm{P}\left\{{ }^{1} \mathrm{H}\right\}$ NMR $\left(400 \mathrm{MHz}, \mathrm{CD}_{3} \mathrm{CN}, \delta \mathrm{ppm}\right):-1.4$ (s)

2.2.3. $\quad\left[\mathrm{Ag}_{2}(\mathrm{dppe})(3-\text { benzyl-1,3-thiazolidine-2-thione })_{2}\right]$. $\left(\mathrm{NO}_{3}\right)_{2}$, 3. Yield, $55 \%$, m.p. $156-157^{\circ} \mathrm{C}$. Anal. Calc: C, 53.49; H, 4.49; N, 2.70, and S; 12.42 Found: C, 53.12; H, 4.27; N,
2.61, and $\mathrm{S} ; 12.08$. IR data $\left(\mathrm{cm}^{-1}\right): \mathrm{v}\left(\mathrm{NO}_{3}{ }^{-}\right)$1307, $\mathrm{v}(\mathrm{C}-\mathrm{N})$ $1223, \mathrm{v}(\mathrm{C}=\mathrm{S}) 1153$, and $\mathrm{v}\left(\mathrm{P}-\mathrm{C}_{\mathrm{ph}}\right) 1097 .{ }^{1} \mathrm{H}$ NMR $(400 \mathrm{MHz}$, $\mathrm{CD}_{3} \mathrm{CN}, \delta$ ppm): 7.42-7.22 ( $\left.m, 30 \mathrm{H}, \mathrm{Ar}-\mathrm{H}\right) ; 4.88(s, 4.01 \mathrm{H}$, $\left.\mathrm{N}-\mathrm{CH}_{2}\right) ; 3.92\left(t, 4 \mathrm{H}, J=8 \mathrm{~Hz}, \mathrm{~N}-\mathrm{CH}_{2}\right) ; 3.12(t, 4.12 \mathrm{H}$, $\left.J=8 \mathrm{~Hz}, \mathrm{~S}-\mathrm{CH}_{2}\right)$; and $2.46\left(s, 4.15 \mathrm{H}, \mathrm{CH}_{2}-\mathrm{CH}_{2}-\mathrm{P}\right) .{ }^{13} \mathrm{C} \mathrm{NMR}$ (400 MHz, $\left.\mathrm{CD}_{3} \mathrm{CN}, \delta \mathrm{ppm}\right): 196.9(\mathrm{C}=\mathrm{S}) ; 135-127$ (8C, C-Ar); 56.9 (C-N); $52.4(\mathrm{C}-\mathrm{N}) ; 27.3(\mathrm{C}-\mathrm{S})$; and $24\left(\mathrm{CH}_{2}-\right.$ $\left.\mathrm{CH}_{2}-\mathrm{P}\right) .{ }^{31} \mathrm{P}\left\{{ }^{1} \mathrm{H}\right\} \mathrm{NMR}\left(400 \mathrm{MHz}, \mathrm{CD}_{3} \mathrm{CN}, \delta \mathrm{ppm}\right): 4.3$ (s)

2.2.4. $\left.\quad\left[\mathrm{Ag}_{2}\left(\mathrm{PPh}_{3}\right)_{2} \text { (3-benzyl-1,3-thiazolidine-2-thione }\right)_{4}\right]$. $\left(\mathrm{NO}_{3}\right)_{2}$, 4. Yield, $54 \%$, m.p. $135-136^{\circ} \mathrm{C}$. Anal. Calc: C, 57.86; $\mathrm{H}, 4.73 ; \mathrm{N}, 3.55$, and $\mathrm{S} ; 16.26$ Found: $\mathrm{C}, 57.72 ; \mathrm{H}, 4.46 ; \mathrm{N}$, 3.38, and $\mathrm{S} ; 16.04$. IR data $\left(\mathrm{cm}^{-1}\right): \mathrm{V}\left(\mathrm{NO}_{3}{ }^{-}\right) 1314, \mathrm{~V}(\mathrm{C}-\mathrm{N})$ 1223, v $(\mathrm{C}=\mathrm{S}) 1154, \mathrm{v}\left(\mathrm{P}-\mathrm{C}_{\mathrm{ph}}\right)$ 1092. ${ }^{1} \mathrm{H}$ NMR $(400 \mathrm{MHz}$, $\left.\mathrm{CD}_{3} \mathrm{CN}, \delta \mathrm{ppm}\right): 7.33-7.15(m, 50.37 \mathrm{H}, \quad \mathrm{Ar}-\mathrm{H}) ; 4.91$ $\left(s, 7.80 \mathrm{H}, \mathrm{N}-\mathrm{CH}_{2}\right) ; 3.94\left(t, 8 \mathrm{H}, J=8 \mathrm{~Hz}, \mathrm{~N}-\mathrm{CH}_{2}\right)$; and 3.18 $\left(t, 7.88 \mathrm{H}, J=8 \mathrm{~Hz}, \mathrm{~S}-\mathrm{CH}_{2}\right) .{ }^{13} \mathrm{C} \mathrm{NMR}\left(400 \mathrm{MHz}, \mathrm{CD}_{3} \mathrm{CN}\right.$, $\delta$ ppm): $196.9(\mathrm{C}=\mathrm{S}) ; 136-127$ (8C, C-Ar); $56.4(\mathrm{C}-\mathrm{N}) ; 52.1$ (C-N); and 26.9 (C-S). ${ }^{31} \mathrm{P}\left\{{ }^{1} \mathrm{H}\right\}$ NMR $\left(400 \mathrm{MHz}, \mathrm{CD}_{3} \mathrm{CN}\right.$, $\delta$ ppm): 8.3 (s)

2.2.5. $\left[\mathrm{Ag}_{2}\right.$ (Tri(o-tolyl)phosphine) ${ }_{2}$ (3-benzyl-1,3-thiazolidine2-thione $\left.)_{4}\right] .\left(\mathrm{NO}_{3}\right)_{2}$, 5. Yield, 37\%, m.p. $144-145^{\circ} \mathrm{C}$. Anal. Calc: C, 59.27; H, 5.22; N, 3.37, and S; 15.54 Found: C, 59.12; $\mathrm{H}, 4.97 ; \mathrm{N}, 3.06$, and $\mathrm{S} ; 15.36$. IR data $\left(\mathrm{cm}^{-1}\right): \mathrm{V}\left(\mathrm{NO}_{3}{ }^{-}\right) 1315$, v $(\mathrm{C}-\mathrm{N}) 1266, \mathrm{v}(\mathrm{C}=\mathrm{S}) 1160$, and $\mathrm{v}\left(\mathrm{P}-\mathrm{C}_{\mathrm{ph}}\right) 1129 .{ }^{1} \mathrm{H} \mathrm{NMR}$ (400 MHz, $\mathrm{CD}_{3} \mathrm{CN}, \delta$ ppm): 7.40-6.62 (m, 44.24H, Ar-H); $4.92\left(s, 8 \mathrm{H}, \mathrm{N}-\mathrm{CH}_{2}\right) ; 3.95\left(t, 7.52 \mathrm{H}, J=8 \mathrm{~Hz}, \mathrm{~N}-\mathrm{CH}_{2}\right) ; 3.21$ $\left(t, 8.35 \mathrm{H}, J=8 \mathrm{~Hz}, \mathrm{~S}-\mathrm{CH}_{2}\right)$; and $2.31\left(s, 17.86 \mathrm{H}, \mathrm{CH}_{3}-\mathrm{Ar}-\mathrm{P}\right)$. ${ }^{13} \mathrm{C} \mathrm{NMR}\left(400 \mathrm{MHz}, \mathrm{CD}_{3} \mathrm{CN}, \delta \mathrm{ppm}\right): 197.1(\mathrm{C}=\mathrm{S}) ; 143-126$ (10C, C-Ar); $56.4(\mathrm{C}-\mathrm{N}) ; 52.1(\mathrm{C}-\mathrm{N}) ; 26.9(\mathrm{C}-\mathrm{S})$; and $20(\mathrm{C}-$ Ar-P). ${ }^{31} \mathrm{P}\left\{{ }^{1} \mathrm{H}\right\}$ NMR (400 MHz, $\left.\mathrm{CD}_{3} \mathrm{CN}, \delta \mathrm{ppm}\right):-27.8$, $37(\mathrm{~s})$

\subsection{In Vitro Antiplasmodial Assay}

2.3.1. In Vitro Culture and Synchronization of P. falciparum. The chloroquine-resistant $P$. falciparum was grown in an incubator at $5 \% \mathrm{CO}_{2}$. The culture was prepared in a $25 \mathrm{~cm}^{3}$ culture flask with filtered vent and maintained in a complete RPMI 1640 culture medium (Invitrogen, USA). Fresh red cells of blood group $\mathrm{O}$ were used as a host to grow the $P$. falciparum, with the initial culture containing $1 \%$ parasitemia at a hematocrit of $2.5 \%$. The parasite density was monitored daily by means of making thin blood smears stained with $10 \%$ Giemsa solution, after which they were observed under the microscope at magnification of 1000x. The parasites were synchronized using a 5\% sorbitol [27] and then cultured for one complete cycle. The P. falciparum infected red blood cell culture with a parasitemia level of approximately 5 to $7 \%$ was used in vitro for the histidine-rich protein (HRP2) assay.

2.3.2. P. falciparum Histidine-Rich Protein 2 (HRP2) Assay. The HRP2 is a specific protein secreted by the $P$. falciparum parasites during their blood stage cycle [28]. The HRP2 assay was carried out according to the procedure specified in the 
literature [29, 30] with some modifications. Briefly, the substance was dissolved in $100 \%$ dimethyl sulfoxide (DMSO) to obtain $5 \mathrm{mg} / \mathrm{ml}$ stock solutions. For each compound stock plate, the compounds $(5 \mathrm{mg} / \mathrm{ml})$ were serially diluted (2-fold dilution) to give 7-point concentrations (ranging from $0.08 \mathrm{mg} / \mathrm{ml}$ to $5 \mathrm{mg} / \mathrm{ml}$ ) in DMSO in wells A1 to A7 of a 96-well plate. $15 \mu \mathrm{l}$ of each serially diluted stock was transferred into watery plates containing $225 \mu \mathrm{l}$ of sterile $\mathrm{H}_{2} \mathrm{O}$. An aliquot of the mixture was used in the HRP2 assay.

Ring-infected RBCs with 5\% parasitemia were adjusted to $0.05 \%$ parasitemia and $1.5 \%$ hematocrit. A total of $190 \mu \mathrm{l}$ of parasitized RBCs at $1.5 \%$ hematocrit were added into each well of the test plate. $10 \mu \mathrm{l}$ of serially diluted compounds from the preprepared plates were transferred to the test plates containing parasitized RBCs after which they were incubated in a candle jar at $37^{\circ} \mathrm{C}$ for $72 \mathrm{~h}$. The final concentrations of the compounds ranged from $0.25 \mu \mathrm{g} / \mathrm{ml}$ to $15.7 \mu \mathrm{g} / \mathrm{ml}$, with the concentration of DMSO being $0.3 \%$.

Chloroquine (CQ) (Sigma, USA), quinine (Q) (Sigma, USA), mefloquine (Mef) (Sigma, USA), and artemisinin (Art) (Sigma, USA) were used as standard control to validate the test. The ranges of the standards concentration were as follows: (1) 27.7-1772.6 nM for CQ, (2) 54.6-3495 $\mathrm{nM}$ for Q, (3) $9.4-601.3 \mathrm{nM}$ for Mef, and (4) $0.8-51.2 \mathrm{nM}$ for Art. Sterile $\mathrm{H}_{2} \mathrm{O}$ and infected RBCs without the tested compounds were the negative controls in this study.

After incubating for $72 \mathrm{~h}$, the test plates were kept at $-80^{\circ} \mathrm{C}$ overnight. After being thawed at room temperature, $100 \mu \mathrm{l}$ of the $P$. falciparum-infected RBC lysates was transferred from the test plates into ELISA plates coated with immunoglobulin M (IgM) capture antibodies (MPFM-55A, ICL, Inc, Newberg, OR, USA) specific for $P$. falciparum HRP2 $(1 \mu \mathrm{g} / \mathrm{ml}$ in phosphate-buffered saline (PBS)). Subsequently, the ELISA plates were incubated in a humidity chamber for $1 \mathrm{~h}$ at room temperature. The plates were washed three times with $0.05 \%$ PBS-Tween 20 (PBST), following which $100 \mu \mathrm{l}$ of the horseradish peroxidaseconjugated $(0.2 \mu \mathrm{g} / \mathrm{ml}$ in PBS $)$ detector antibodies (MPFG-55P, ICL, Inc., Newberg, OR, USA) was added to each well. Incubation was done in a humidity chamber for $1 \mathrm{~h}$ at room temperature. A subsequent washing step as mentioned above was followed by the addition of $100 \mu \mathrm{l}$ of 3,3', 5,5-tetramethylbenzidine (TMB) chromogen (Zymed Lab., Inc., San Francisco, CA, USA) into each well. After being incubated for $10 \mathrm{~min}$ in the absence of light, $50 \mu \mathrm{l}$ of $1 \mathrm{M}$ sulfuric acid was added to the wells. The absorbance was determined by an ELISA plate reader at a wavelength of $450 \mathrm{~nm}$ (FLUOstar Omega, Germany). Finally, the collected data were keyed into to the HN-nonLin software (http://malaria.farch.net) to obtain the $50 \%$ effective concentration $\left(\mathrm{EC}_{50}\right)$ values directly from the graphs. All tests were performed in triplicates.

2.4. In Vitro Cytotoxicity Assay. The Vero cells, the kidney epithelial cells isolated from African green monkey, were used as a representative of normal cell lines in cytotoxicity assay for determination of cytotoxic activity of each compound. The Vero cells were maintained in complete DMEM culture medium containing $25 \mathrm{mM}$ HEPES, $0.4 \%$ sodium bicarbonate $\left(\mathrm{NaHCO}_{3}\right), 100 \mathrm{U}$ of Penstrep $(100 \mathrm{U}$ of each penicillin and streptomycin) supplemented with $10 \%$ fetal bovine serum (FBS). The cytotoxicities of the synthesized compounds were measured via 3-(4, 5dimethylthiazol-2-yl)-2, 5-diphenyltetrazolium bromide (MTT) assay [31]. Prior to the day of testing, the stock plates were prepared by serially diluting (2-fold dilution) the compounds $(2.5 \mathrm{mg})$ to 7 -point concentrations (ranging from $0.08 \mathrm{mg} / \mathrm{ml}$ to $5 \mathrm{mg} / \mathrm{ml}$ ) with DMSO. Then, a $6 \mu \mathrm{l}$ of serially diluted stocks was transferred into a 96-well plate containing $294 \mu \mathrm{l}$ of complete DMEM media (medium plates). Subsequently, $100 \mu \mathrm{l}$ of the compounds was taken from the medium plate (as prepared) and added to the test plate containing $100 \mu \mathrm{l}$ of complete DMEM media with $1 \times 10^{3}$ Vero cells. The final concentration ranged between $0.78 \mu \mathrm{g} / \mathrm{ml}$ and $25 \mu \mathrm{g} / \mathrm{ml}$. The final concentration of DMSO in all the tests was less than $1 \%$. All tests were performed in triplicates.

The positive control for the cell growth was the cell suspension without the test substance, while the negative control cell suspension with $0.05 \%$ Triton $\times 100$. The cultures were incubated at $37^{\circ} \mathrm{C}$ in $5 \% \mathrm{CO}_{2}$ incubator for $72 \mathrm{~h}$. Then, $50 \mu \mathrm{l}$ of MTT solution ( $5 \mathrm{mg}$ MTT in $1 \mathrm{~mL}$ PBS and $2.5 \mathrm{~mL}$ of DMEM media) was added to each well. Following further incubation for $4 \mathrm{~h}$ at $37^{\circ} \mathrm{C}$ and $5 \% \mathrm{CO}_{2}$ incubator, the medium was removed and replaced with $200 \mu \mathrm{l}$ of DMSO to solubilize the MTT formazan product. The solution was mixed for $15 \mathrm{~min}$ and once for $30 \mathrm{~s}$ before the absorbance and was measured using a microplate reader (FLUOstar Omega, Germany) at a wavelength $540 \mathrm{~nm}$. The $50 \%$ effective concentration $\left(\mathrm{EC}_{50}\right)$ of antiplasmodial activity and $50 \%$ cytotoxic concentration $\left(\mathrm{CC}_{50}\right)$ were determined based on a dose response curve. A selectivity index (SI)-which corresponded to the ratio between the antiplasmodial and cytotoxic activities-was calculated according to the following formula:

$$
\mathrm{SI}_{\text {Plasmodium }}=\frac{\mathrm{CC}_{50 \text { normal cell lines }}}{\mathrm{EC}_{50 \text { Plasmodium }}} .
$$

2.5. Antiproliferative Assay. The three human cancer cell lines used in the present study, human breast cancer cell lines, MDA-MB-231 and MCF-7, and human colon cancer cell line, and HT-29 were purchased from American Type Culture Collection (ATCC, Rockville, MD, USA). Cells were grown as monolayer culture in Dulbecco's modified Eagle medium (DMEM) (Gibco BRL, Grand Island, NY, USA) supplemented with $10 \%$ fetal bovine serum (Gibco BRL), $25 \mathrm{mM}$ HEPES (Sigma), and 1\% antibiotic (Gibco BRL) in tissue culture flasks in a humidified incubator at $37^{\circ} \mathrm{C}$ at an atmosphere of $95 \%$ air and 5\% carbon dioxide. Cells were kept in the logarithmic growth phase by routine passage every 2-3 days using $0.025 \%$ trypsin-EDTA treatment.

Sulforhodamine B (SRB) assay was carried out as described in the previous studies to determine the $50 \%$ growth inhibition $\left(\mathrm{GI}_{50}\right)$ values of all the compounds [32]. Initially, 
the cells were seeded in 96-well plates at a density of either $1 \times 10^{5}$ cells $/ \mathrm{ml}$ (MCF-7) or $2 \times 10^{5}$ cells/ml (MDA-MB-231 and HT-29), after which incubation was done overnight to allow the cells to adhere to the bottom of the plates. The next day, some of the plates were processed to determine the density at time zero $\left(t_{0}\right)$. According to the National Cancer Institute (NCI), the use of $t_{0}$ control allows the determination of the amount of cells killed as well as the net inhibition of growth [32]. The cells in the remaining plates were treated with compounds $1,2,3,4$, or 5 at concentrations ranging from $0.383-12.269 \mu \mathrm{M}, 0.378-12.103 \mu \mathrm{M}$, $0.657-21.031 \mu \mathrm{M}, 0.496-15.846 \mu \mathrm{M}$, and $1.881-60.176 \mu \mathrm{M}$, respectively. After $48 \mathrm{~h}$, the cells were fixed in the plates using $50 \mu \mathrm{l}$ of $50 \%(\mathrm{w} / \mathrm{v})$ trichloroacetic acid (TCA) solution, following which they were further incubated at $4^{\circ} \mathrm{C}$ for $1 \mathrm{~h}$. The plates were then washed five times with tap water and air-dried prior to staining with $100 \mu \mathrm{l}$ of $0.4 \%$ (w/v) SRB staining solution. Further incubation was done for $10 \mathrm{~min}$ at room temperature. Subsequently, the plates were washed three times with $1 \%(\mathrm{v} / \mathrm{v})$ acetic acid to remove the unbound stains. After air-drying, the wells were added with $200 \mu \mathrm{l}$ of $10 \mathrm{mM}$ Trizma base and shaken well for $10 \mathrm{~min}$. Henceforth, the absorbance was measured using a microplate reader at a wavelength of $490 \mathrm{~nm}$. All experiments were carried out in triplicates. $\mathrm{GI}_{50}$ was calculated using the following formula:

$$
\mathrm{GI}_{50}=\mathrm{OD}_{\text {sample }}-\frac{\mathrm{OD}_{t_{0}}}{\mathrm{OD}_{\text {control }}-\mathrm{OD}_{t_{0}}} \times 100 .
$$

\section{Results and Discussion}

The synthesized 3-benzyl-1,3-thiazolidine-2-thione ligands were reacted with silver nitrate and one of the following: (a) 1,2-bis(diphenylphosphino)methane (dppm), (b) 1,1-bis (diphenylphosphino)ferrocene (dppf), (c) 1,1-bis(diphenylphosphino)ethane (dppe), (d) triphenylphosphine $\left(\mathrm{PPh}_{3}\right)$, or (e) tri(o-tolyl)phosphine. The molar ratio $(\mathrm{Ag}: \mathrm{S}: \mathrm{P})$ of the three reactants was $2: 2: 1$ if phosphines $(\mathbf{a})-(\mathbf{c})$ were used, or 1:2:1 if (d) or (e) were used. The solvent was a mixture of acetonitrile/methanol. Based on the reaction between silver, thiazolidine, mono-, or bidentate phosphine ligands, complexes $1,3,4$, and 5 produced a clear black solution, while complex 2, a clear orange solution. According to the ${ }^{1} \mathrm{H}$ NMR data, the synthesized silver(I) complexes were found to be nonhygroscopic and thus stable (free from decomposition) for at least a year of monitoring. Besides, all the complexes were found to have good solubility in certain organic solvents such as acetonitrile, dimethyl sulfoxide, diethyl ether, and dimethylformamide.

3.1. Spectroscopic Data Analysis. The 3-benzyl-1,3-thiazolidine2-thione ligand offers three types of donor atoms which are thiocarbonyl sulfur atom, the nitrogen atom, and the endocyclic sulfur atom. $\mathrm{v}(\mathrm{C}=\mathrm{S})$ in complexes $\mathbf{1}$ to $\mathbf{5}$ were assigned at $1275-1030 \mathrm{~cm}^{-1}$ that observed to be shifted to a lower energy as compared to the free 3-benzyl-1,3thiazolidine-2-thione ligand. The displacement to lower energies of the thioamide band shows the coordination to silver metal through the $\mathrm{C}=\mathrm{S}$ sulfur atom. Meanwhile, the $\checkmark(\mathrm{C}-\mathrm{N})$ at $1360-1180 \mathrm{~cm}^{-1}$ in the spectra was observed to shift to higher energies; this did not occur in the free ligand. The nitrogen and sulfur within the ring containing electron pairs which were in resonance with the thiocarbonyl group lead to higher delocalization of electrons and lower the ability of coordination [33]. The presence of phosphine ligand was confirmed by its characteristic $\mathrm{V}\left(\mathrm{P}-\mathrm{C}_{\mathrm{ph}}\right)$ band in the range of $1130-1090 \mathrm{~cm}^{-1}$ and a sharp band at about $1300 \mathrm{~cm}^{-1}$, indicating the existence of noncoordinated $\mathrm{NO}_{3}{ }^{-}$ in all complexes.

In the ${ }^{1} \mathrm{H}$ NMR spectra of the thiazolidine ligand, there were signals observed in the $\delta 7.29-\delta 7.39 \mathrm{ppm}$ region which corresponded to aromatic protons. As for the complexes, the additional aromatic protons observed at the $\delta 6.68-7.50 \mathrm{ppm}$ region indicated the existence of aromatic groups from the phosphine ligand. Also, the peaks for the $\mathrm{N}-\mathrm{CH}_{2}$ and $\mathrm{S}-\mathrm{CH}_{2}$ signals in all the complexes were shifted slightly upfield relative to the free thiazolidine ligand. For complex 1, a singlet signal was seen at $\delta 3.67 \mathrm{ppm}$ in light of the $-\mathrm{CH}_{2}$ protons in the dppm ligand. As for complex 3 , there was a peak at $\delta 2.46 \mathrm{ppm}$ corresponding to the four protons of the ethylene group in the dppe ligand. Meanwhile, the two broad signals at $\delta 4.35 \mathrm{ppm}$ and $\delta 4.17 \mathrm{ppm}$ for complex 2 were attributable to the cyclopentyl protons of the dppf ligand. For complex $\mathbf{5}$, there was a singlet peak at $\delta 2.31 \mathrm{ppm}$ owing to the $-\mathrm{CH}_{3}$ protons in the orthoposition of the tri(otolyl)phosphine ligands.

The FTIR and ${ }^{1} \mathrm{H}$ NMR data strongly suggested the coordination between the thiazolidine ligand and silver centre via the thione sulfur. In the ${ }^{13} \mathrm{C}$ NMR spectrum, the proof of the bonding between the aforementioned molecules was also reflected by the $\mathrm{C}=\mathrm{S}$ signal, in which a change in the chemical shift value (ca. $\delta 0.2 \mathrm{ppm}$ ) was present; again, this was not seen as in free thiazolidine ligands [33]. A downfield shift in $\delta \mathrm{C}-\mathrm{N}$ and $\delta \mathrm{C}$-S relative to the free thiazolidine ligands was also observed. Furthermore, there were additional carbon peaks in the spectra at $\delta 25.3 \mathrm{ppm}$ for complex 1, $\delta 74.8 \mathrm{ppm}$ and $\delta 72.8 \mathrm{ppm}$ for complex 2, $\delta 24.4 \mathrm{ppm}$ for complex 3, and $\delta 20.5 \mathrm{ppm}$ for complex 5, all of which denote the carbon signals from the corresponding phosphine ligands.

It was observed that in comparison to free phosphine ligands, the ${ }^{31} \mathrm{P}\left\{{ }^{1} \mathrm{H}\right\}$ NMR resonances in all the complexes were shifted downfield in light of the formation of $\sigma$ bonds between $\mathrm{P}$ and Ag. As per the ${ }^{31} \mathrm{P}\left\{{ }^{1} \mathrm{H}\right\}$ NMR data of complexes 2, 3, and 4, the singlet peaks can be ascribed to two chemically-equivalent $\mathrm{P}$ atoms each in dppf and dppe, as well as one in triphenylphosphine. However, the spectrum of compound 1 surprisingly showed two different singlet peaks at $\delta 5.2$ and $\delta 8.0 \mathrm{ppm}$. In contrast, its corresponding free dppm ligand had only one singlet peak. This phenomenon could presumably be attributed to the fact that there were nonequivalent phosphorus atoms in the complex probably due to the ${ }^{31} \mathrm{P}_{-}{ }^{109 / 107} \mathrm{Ag}$ coupling [34-36]. For complex 5, the ${ }^{31} \mathrm{P}\left\{{ }^{1} \mathrm{H}\right\}$ NMR spectrum revealed two singlet peaks at $\delta-27.8$ and $38 \mathrm{ppm}$. The peak which was at an unusually low frequency $(\delta-27.8 \mathrm{ppm})$ was also reported by Rizatto et. al. that reflected the indication of the formation of an unexpected 


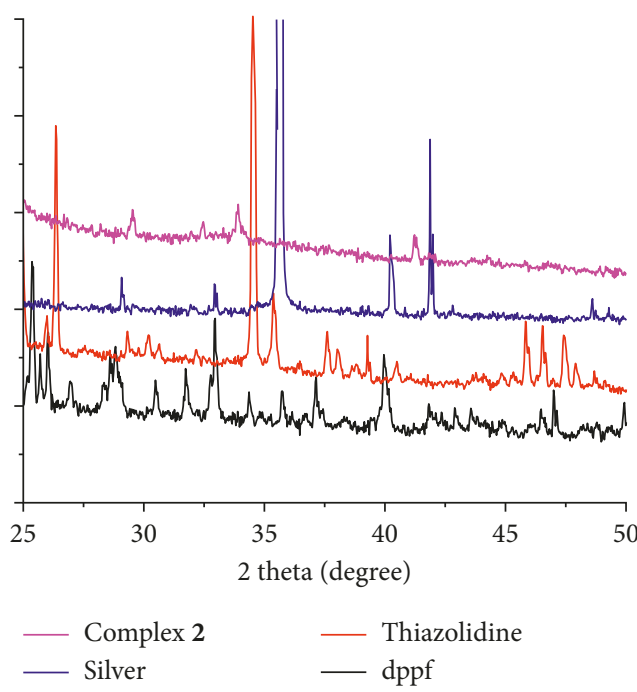

(a)

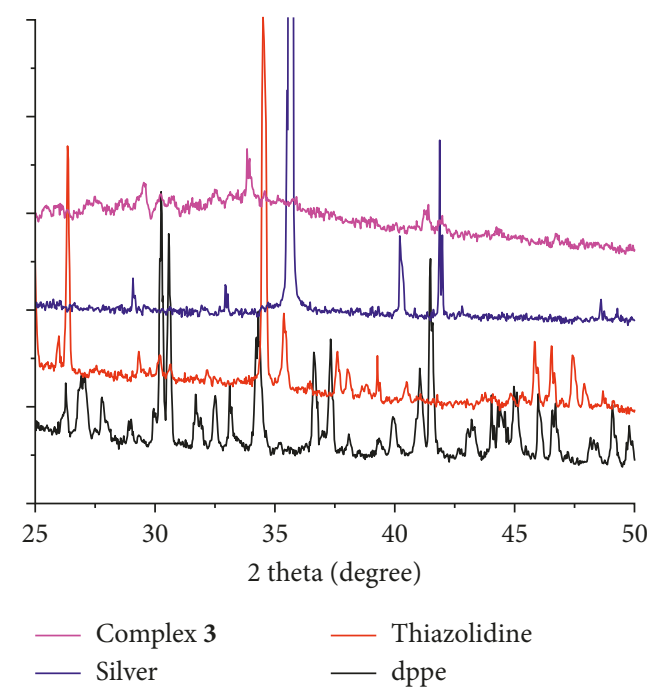

(b)

FIgURE 2: PXRD diffraction patterns of complexes 2 and 3.

product with the presence of an uncoordinated $\mathrm{P}$-atom from the tri(o-tolyl)phosphine ligand $[37,38]$. Since we are yet to obtain the X-ray crystallography, it is worth noting that the affirmations of complex $\mathbf{5}$ structures are still uncertain.

The obtained complexes were subjected to EDX analysis (refer Supplementary Materials (available here)) to confirm the presence of silver metal in each compound. The analysis revealed the presence of silver metal, which was in agreement with the molar ratio used as well as all the other components that were expected to be present.

3.2. Powder X-Ray Diffraction Analysis (PXRD). The growth of crystals sufficient for X-ray single crystal analysis of all the synthesized complexes was attempted several times by utilising various techniques. However, it is difficult to crystallize the silver complexes especially containing sulfur and nitrogen as donor atoms due to its tendency of intramolecular interactions and formation into a polymeric state $[39,40]$. Thus, we probed the complexes for powder X-ray diffraction analysis to obtain its phase identification, determination of unit cell dimensions, as well as measurement of sample purity. These data complement with our findings from other spectroscopic methods that suggest the structural rearrangement of the complexes.

The PXRD diffractograms were obtained within the $2 \theta$ range of $25-50^{\circ}$ (refer Supplementary Materials (available here)). The diffractogram of each complex was compared to their corresponding thiazolidine and phosphine ligands based on the diffraction pattern of $\mathrm{AgNO}_{3}$ as a standard reference (and starting material). The diffractogram patterns demonstrated the silver characteristics of face-centred cubic. Nonetheless, the broader peaks observed were due to the noncrystalline sample with relatively smaller sizes (ca. $<20 \AA$ ) $[25,36]$. On Comparison of peaks of the complexes $\mathbf{2}$ and $\mathbf{3}$, $\mathrm{AgNO}_{3}$, 3-benzyl-1,3-thiazolidine-2-thione and its phosphine ligand (Figure 2) indicated the successful complex formation due to the presence of matched peaks which show the insertion of ligands to the metal center. The prominent peak for the (111) unit cell dimensions observed at $2 \theta$ value ca. $34^{\circ}$ slightly shifted from the $\mathrm{AgNO}_{3}$ peak (ca. $36^{\circ}$ ) and confirmed the purity of the synthesized compounds which was also justified by the CHN, FTIR, and NMR results.

3.3. Thermogravimetric Analysis (TGA). The thermal decompositions of complexes 1-5 were carried out to study its decomposition behaviour (refer Supplementary Materials (available here)). The TGA curved for complex 1 showed the decomposition of the silver metal to $\mathrm{Ag}_{2} \mathrm{O}$ and the phosphine molecules to its oxide form which was $34.99 \%$ (theoretical: $35 \%$ ) starting from $450^{\circ} \mathrm{C}$ to $900^{\circ} \mathrm{C}$ and for complex 3 was $32.41 \%$ (theoretical: $34.54 \%$ ) starting from $490^{\circ} \mathrm{C}$ to $900^{\circ} \mathrm{C}$. Other than that, the percentage decomposition of $\mathrm{Ag}$, phosphine, and Fe molecules to the oxide forms for complex 2 was $40.16 \%$ (theoretical: $39.32 \%$ ) starting from $710^{\circ} \mathrm{C}$ to $886^{\circ} \mathrm{C}$. Meanwhile, for complex 4 , the percentage of decomposition of Ag was $25.73 \%$ (theoretical: $29.38 \%$ ) between $500^{\circ} \mathrm{C}$ and $880^{\circ} \mathrm{C}$, while that for complex 5 was $25.27 \%$ (theoretical: $27.89 \%$ ) from $300^{\circ} \mathrm{C}$ to $900^{\circ} \mathrm{C}$. Thus, with respect to the data, it was shown that the experimental mass losses were in agreement to the theoretical values.

3.4. Antiplasmodial Activity. Thiazolidine derivatives have been extensively studied for their antimicrobial activities against pathogenic bacteria, fungi, anti-HIV, and $P$. falciparum $[41,42]$. In addition, the introduction of an amide bond with a heterocyclic ring system (4-thiazolidine) to the lateral side chain of 4-aminoquinoline (an antimalarial agent) has been shown to improve the antimalarial activity of this compound [43]. In the present study, five $\mathrm{Ag}$ complexes with thiazolidine ligand showed promising in vitro antiplasmodial activities against chloroquine-resistant P. falciparum of $\mathrm{K} 1$ strain. The $\mathrm{EC}_{50}$ values of the complexes 
TABLE 2: Antiplasmodial and cytotoxicity activities of silver(I) complexes.

\begin{tabular}{lccc}
\hline Complexes & $\begin{array}{c}\text { P. falciparum K1 } \\
\mathrm{EC}_{50} \pm \mathrm{SD}(\mu \mathrm{M})\end{array}$ & $\begin{array}{c}\text { Vero cell line } \\
\mathrm{CC}_{50} \pm \mathrm{SD}(\mu \mathrm{M})\end{array}$ & SI \\
\hline $\mathbf{1}$ & $2.5 \pm 0.1$ & $2.9 \pm 0.6$ & 1.1 \\
$\mathbf{2}$ & $1.7 \pm 0.2$ & $>21$ & $>12.4$ \\
$\mathbf{3}$ & $1.5 \pm 0.1$ & $5.2 \pm 0.9$ & 3.5 \\
$\mathbf{4}$ & $1.04 \pm 0.02$ & $1.6 \pm 0.2$ & 1.6 \\
$\mathbf{5}$ & $1.8 \pm 0.1$ & $11.8 \pm 2.5$ & 6.6 \\
\hline
\end{tabular}

fell within the acceptable cutoff values, which were more than $1-5 \mu \mathrm{M}$ for further in vivo preclinical antimalarial studies [44]. The cytotoxic effects of each complex on Vero cells were assessed to determine the selectivity index or ratio, of cytotoxicity to biological activity (SI). The antiplasmodial activities of the complexes were considered to be specific and safe when the SI was more than $10[44,45]$. Of all the synthesized Ag complexes, complex 2 exhibited highest SI followed by complex $\mathbf{5}$, as shown in Table 2 .

3.5. Antiproliferative Activity. Breast and colon cancer are the most common cancer worldwide [46, 47]. According to the National Cancer Registry 2007 of Malaysia, breast and colorectal cancer also are the most common cancer in Malaysia [48]. One of the main treatments for cancer is chemotherapy $[49,50]$; however, the development of drug resistance $[51,52]$ and drug toxicity [53] results in significant relapse as well as decreased overall survival rates in cancer patients [54]. Thus, searching for potential drug with high efficacy and low drug toxicity remains a huge challenge in the anticancer drug discovery research and development.

Clinical successes of cisplatin, carboplatin, and oxaliplatin have resulted in the usage of metal complexes in the treatment of malignant tumors [55]. The development of anticancer drugs from coinage metals such as Ag is currently a very active field [56]. Previous studies have suggested that Ag-mixed ligand complexes have antiproliferative activities [57]. Hence, the antiproliferative potential of our newly synthesized $\mathrm{Ag}$ complexes with thiazolidine and phosphine ligand was verified via an experiment on different human carcinomas.

The evaluation of new anticancer drug agents through preclinical testing using cell culture is important to eliminate unsuitable candidates before pursuing into clinical research. In the present study, sulforhodamine B (SRB) was used to evaluate the anticancer properties of our drug candidates. Although MTT has been the gold standard for cytotoxicity assays, it showed interactions with many compounds and thus may yield inaccurate results $[58,59]$. On the contrary, SRB assay is highly reproducible, and this assay is dependent on the protein content, thus test compound interference can be avoided [60].

The antiproliferative activities were evaluated on three human cancer cell lines, that is, metastatic breast carcinoma (MDA-MB-231), breast adenocarcinoma (MCF-7), and colon carcinoma (HT-29). Dose-response curves were constructed to calculate the $\mathrm{GI}_{50}(\mu \mathrm{M})$ values, which
TABLE 3: $\mathrm{GI}_{50}(\mu \mathrm{M})$ of different cancer cell lines after $48 \mathrm{~h}$ of exposure to compounds.

\begin{tabular}{lccc}
\hline Complexes & \multicolumn{3}{c}{$\mathrm{GI}_{50} \pm \mathrm{SD}(\mu \mathrm{M})$} \\
& MDA-MB-231 & MCF-7 & HT-29 \\
\hline $\mathbf{1}$ & $1.7 \pm 1.3$ & $0.5 \pm 0.2$ & $1.6 \pm 0.7$ \\
$\mathbf{2}$ & $1.9 \pm 0.3$ & $>21.03$ & $>21.03$ \\
$\mathbf{3}$ & $1.0 \pm 0.1$ & $0.2 \pm 0.1$ & $0.4 \pm 0.3$ \\
$\mathbf{4}$ & $1.5 \pm 0.3$ & $1.2 \pm 0.2$ & $1.5 \pm 0.9$ \\
$\mathbf{5}$ & $4.7 \pm 1.1$ & $2.9 \pm 0.9$ & $15.1 \pm 1.9$ \\
\hline
\end{tabular}

corresponded to the concentrations required to inhibit the growth of $50 \%$ of the cells. Table 3 shows the $\mathrm{GI}_{50}$ values of the synthesized compounds against the tested human carcinomas.

The selectivity of Ag complexes towards the tumor cells was ligand-dependent, which could probably be attributable to the stability and hydrophilicity-lipophilicity of the complexes formed by the type of the ligand [61]. Interestingly, compound 2 was selective to inhibit the $50 \%$ of MDA-MB-231 cell growth $\left(\mathrm{GI}_{50}=1.9 \pm 0.3 \mu \mathrm{M}\right)$, while compound 5 acted more potent to inhibit breast carcinoma growth $\left(\mathrm{GI}_{50}\right.$ : MDA-MB-231 $=4.7 \pm 1.1 \mu \mathrm{M}$; MCF-7 $=2.9 \pm$ $0.9 \mu \mathrm{M})$ instead of colon carcinoma and HT-29 $\left(\mathrm{GI}_{50}=15.1 \pm 1.9 \mu \mathrm{M}\right)$. Fichtner et al. 2012 reported that silver-carbene complexes were a potent cytotoxic and resistant-breaking anticancer agent, but unfortunately, their efficacy was at the expense of high toxic effect and low selectivity in in vivo setting [62]. However, the type of ligands that attached to the metal can contribute to its anticancer properties as they can be involved in target recognition and interfere in biochemical pathways [63]. The presence of phosphine ligands increases the lipophilicity and membrane permeability of metal-based complexes that make them active [64]. On the contrary, thiazolidine was known to exert anticancer activity mainly via PPAR $\gamma$-independent mechanism of actions [65, 66]. Our synthesized Ag complexes with bioactive thiazolidine and phosphine ligands were able to halt the proliferation of breast and colon cancer cells, thus warranting further investigations for its mechanism of action in vivo.

\section{Conclusions}

In conclusion, a series of five silver(I) complexes with phosphines and 3-benzyl-1,3-thiazolidine-2-thione have been successfully prepared and characterized by spectroscopic methods. The antimalarial activities of all the complexes have been investigated, whereby it was found that complex 2 had the highest SI value (more than 12.4) followed by complex $\mathbf{5}$ (6.6). The relatively high SI value makes complex 2 promising for further investigations towards its development as an antimalarial drug. The anticancer applications of all the synthesized compounds have also been explored and noted to concur with the results for antiplasmodial activity, whereby complex 2 was the most potent. Complex 2 was selective for MDA-MB-231 cells while complex $\mathbf{5}$ acted predominantly on breast carcinoma cells 
rather than those of colon carcinoma. Thus, with these findings, we have provided a preliminary insight into the potential agents that have the ability to act as dual purpose (anticancer and antimalarial) drugs, and in light of that, more in-depth studies on their molecular mechanisms of action are warranted.

\section{Data Availability}

The data used to support the findings of this study are available from the corresponding author upon request.

\section{Conflicts of Interest}

The authors declare that there are no conflicts of interest regarding the publication of this paper.

\section{Acknowledgments}

This work was supported by the Fundamental Research Grant Scheme (FRGS) (Grant no. FP047-2014A) and University of Malaya IPPP Grant (Grant no. PG001-2015A).

\section{Supplementary Materials}

Spectra data for all complexes such as FTIR (see Figures S1-S5), NMR (see Figures S6-S22), EDX (see Figures S23-S27), PXRD (see Figures S28-S30), and TGA (see Figures S31-S35) are available on the journal's website. (Supplementary Materials)

\section{References}

[1] T.-H. Huang, J. Yan, H. Yang, C. Tan, and Y. Yang, "Synthesis, structures, and properties of polynuclear silver complexes containing tetra-phosphine ligand with Ag .C interactions," Australian Journal of Chemistry, vol. 69, no. 3, pp. 336-342, 2016.

[2] J. M. Antelo, L. Adrio, B. Bermúdez et al., "Spectroscopic and solid state characterization of bimetallic terdentate [C,N,S] thiosemicarbazone palladium(II) metallacycles with bridging and chelating $[P, P]$ diphosphine ligands," Journal of Organometallic Chemistry, vol. 740, pp. 83-91, 2013.

[3] R. Sharma, T. S. Lobana, M. Kaur et al., "Variable coordinating activity of sulfur in silver(I) complexes with thiophene based N1-substituted thiosemicarbazones: first case of thiopheneyl-thione sulfur bridging in a dinuclear complex," Journal of Chemical Sciences, vol. 128, no. 7, pp. 1103-1112, 2016.

[4] M. Aufiero, F. Proutiere, and F. Schoenebeck, "Redox reactions in palladium catalysis: on the accelerating and/or inhibiting effects of copper and silver salt additives in cross-coupling chemistry involving electron-rich phosphine ligands," Angewandte Chemie International Edition, vol. 51, no. 29, pp. 7226-7230, 2012.

[5] R. Ramachandran, G. Prakash, P. Vijayan, P. Viswanathamurthi, and J. G. Malecki, "Synthesis of heteroleptic copper(I) complexes with phosphine-functionalized thiosemicarbazones: an efficient catalyst for regioselective $\mathrm{N}$-alkylation reactions," Inorganica Chimica Acta, vol. 464, pp. 88-93, 2017.
[6] M. Porchia, F. Tisato, M. Zancato, V. Gandin, and C. Marzano, "In vitro antitumor activity of water-soluble copper(I) complexes with diimine and monodentate phosphine ligands," Arabian Journal of Chemistry, 2017, In press.

[7] R. S. Corrêa, M. M. da Silva, A. E. Graminha et al., "Ruthenium(II) complexes of 1,3-thiazolidine-2-thione: cytotoxicity against tumor cells and anti-Trypanosoma cruzi activity enhanced upon combination with benznidazole," Journal of Inorganic Biochemistry, vol. 156, pp. 153-163, 2016.

[8] K. H. Lam, R. Gambari, M. C. W. Yuen et al., "The preparation of 2,6-disubstituted pyridinyl phosphine oxides as novel anticancer agents," Bioorganic and Medicinal Chemistry Letters, vol. 19, no. 8, pp. 2266-2269, 2009.

[9] K. Fourmy, M. Gouygou, O. Dechy-Cabaret, and F. BenoitVical, "Gold(I) complexes bearing phosphole ligands: synthesis and antimalarial activity," Comptes Rendus Chimie, vol. 20, no. 4, pp. 333-338, 2017.

[10] M. Navarro, F. Vásquez, R. A. Sánchez-Delgado, H. Pérez, V. Sinou, and J. Schrével, "Toward a novel metal-based chemotherapy against tropical diseases. 7. Synthesis and in vitro antimalarial activity of new gold-chloroquine complexes," Journal of Medicinal Chemistry, vol. 47, no. 21, pp. 5204-5209, 2004.

[11] S. Gao, Z. F. Li, M. Liu et al., "A series of silver(I) complexes with bis[2-(diphenylphosphino)phenyl]ether (DPEphos) and bis(diphenylphosphino)ethane (dppe): synthesis, structural characterization and photophysical properties," Polyhedron, vol. 83, pp. 10-15, 2014.

[12] A. Verma and S. K. Saraf, "4-Thiazolidinone-a biologically active scaffold," European Journal of Medicinal Chemistry, vol. 43, no. 5, pp. 897-905, 2008.

[13] N. C. Desai, A. Dodiya, and N. Shihory, "Synthesis and antimicrobial activity of novel quinazolinone-thiazolidinequinoline compounds," Journal of Saudi Chemical Society, vol. 17 , no. 3, pp. 259-267, 2013

[14] WHO, World Health Statistics 2015, World Health Organization, Geneva, Switzerland, 2015.

[15] A. Kascatan-Nebioglu, M. J. Panzner, C. A. Tessier, C. L. Cannon, and W. J. Youngs, "N-heterocyclic carbenesilver complexes: a new class of antibiotics," Coordination Chemistry Reviews, vol. 251, no. 5-6, pp. 884-895, 2007.

[16] M. J. Carter, K. Tingley-Kelley, and R. A. Warriner Iii, "Silver treatments and silver-impregnated dressings for the healing of leg wounds and ulcers: a systematic review and meta-analysis," Journal of the American Academy of Dermatology, vol. 63, no. 4, pp. 668-679, 2010.

[17] R. Ahmad Khan, K. Al-Farhan, A. de Almeida et al., "Lightstable bis(norharmane)silver(I) compounds: synthesis, characterization and antiproliferative effects in cancer cells," Journal of Inorganic Biochemistry, vol. 140, pp. 1-5, 2014.

[18] E. R. Jamieson and S. J. Lippard, "Structure, recognition, and processing of cisplatin-DNA adducts," Chemical Reviews, vol. 99, no. 9, pp. 2467-2498, 1999.

[19] L. P. Rybak, D. Mukherjea, S. Jajoo, and V. Ramkumar, "Cisplatin ototoxicity and protection: clinical and experimental studies," Tohoku Journal of Experimental Medicine, vol. 219, no. 3, pp. 177-186, 2009.

[20] C. Hemmert, A. Fabié, A. Fabre, F. Benoit-Vical, and H. Gornitzka, "Synthesis, structures, and antimalarial activities of some silver(I), gold(I) and gold(III) complexes involving $N$-heterocyclic carbene ligands," European Journal of Medicinal Chemistry, vol. 60, pp. 64-75, 2013. 
[21] R. Hooft van Huijsduijnen, R. K. Guy, K. Chibale et al., "Anticancer properties of distinct antimalarial drug classes," PLoS One, vol. 8, no. 12, Article ID e82962, 2014.

[22] C. N. Kundu, S. Das, A. Nayak, S. R. Satapathy, D. Das, and S. Siddharth, "Anti-malarials are anti-cancers and vice versa-one arrow two sparrows," Acta Tropica, vol. 149, pp. 113-127, 2015.

[23] A. Nzila, J. Okombo, R. P. Becker, R. Chilengi, T. Lang, and T. Niehues, "Anticancer agents against malaria: time to revisit?," Trends in Parasitology, vol. 26, no. 3, pp. 125-129, 2010.

[24] M. M. Alhamadsheh, N. C. Waters, D. P. Huddler, M. Kreishman-Deitrick, G. Florova, and K. A. Reynolds, "Synthesis and biological evaluation of thiazolidine-2-one 1,1dioxide as inhibitors of Escherichia coli $\beta$-ketoacyl-ACPsynthase III (FabH)," Bioorganic and Medicinal Chemistry Letters, vol. 17, no. 4, pp. 879-883, 2007.

[25] P. Aslanidis, P. J. Cox, S. Divanidis, and P. Karagiannidis, "Diphosphines as bridging ligands in polymeric and dimeric thione-S-ligated $\mathrm{Ag}(\mathrm{I})$ nitrate complexes," Inorganica Chimica Acta, vol. 357, no. 9, pp. 2677-2686, 2004.

[26] R. Sultana, T. S. Lobana, R. Sharma et al., "Heterocyclic thioamide derivatives of coinage metals $(\mathrm{Cu}, \mathrm{Ag})$ : synthesis, structures and spectroscopy," Inorganica Chimica Acta, vol. 363 , no. 13 , pp. 3432-3441, 2010.

[27] C. Lambros and J. P. Vanderberg, "Synchronization of Plasmodium falciparum erythrocytic stages in culture," Journal of Parasitology, vol. 65, no. 3, pp. 418-420, 1979.

[28] H. Noedl, W. H. Wernsdorfer, R. S. Miller, and C. Wongsrichanalai, "Histidine-rich protein II: a novel approach to malaria drug sensitivity testing," Antimicrobial Agents and Chemotherapy, vol. 46, no. 6, pp. 1658-1664, 2002.

[29] H. Noedl, J. Bronnert, K. Yingyuen, B. Attlmayr, H. Kollaritsch, and M. Fukuda, "Simple histidine-rich protein 2 double-site sandwich enzyme-linked immunosorbent assay for use in malaria drug sensitivity testing," Antimicrobial Agents and Chemotherapy, vol. 49, no. 8, pp. 3575-3577, 2005.

[30] M. R. Mohd Abd Razak, A. Afzan, R. Ali et al., "Effect of selected local medicinal plants on the asexual blood stage of chloroquine resistant Plasmodium falciparum," BMC Complementary and Alternative Medicine, vol. 14, no. 1, p. 492, 2014.

[31] T. Mosmann, "Rapid colorimetric assay for cellular growth and survival: application to proliferation and cytotoxicity assays," Journal of Immunological Methods, vol. 65, no. 1-2, pp. 55-63, 1983.

[32] S. L. Holbeck, J. M. Collins, and J. H. Doroshow, "Analysis of food and drug administration-approved anticancer agents in the NCI60 panel of human tumor cell lines," Molecular Cancer Therapeutics, vol. 9, no. 5, pp. 1451-1460, 2010.

[33] J. D. S. Chaves, F. Neumann, T. M. Francisco et al., "Synthesis and cytotoxic activity of gold(I) complexes containing phosphines and 3-benzyl-1,3-thiazolidine-2-thione or 5phenyl-1,3,4-oxadiazole-2-thione as ligands," Inorganica Chimica Acta, vol. 414, pp. 85-90, 2014.

[34] T. S. Lobana, S. Khanna, and A. Castineiras, "Sulfur bridging by acetophenone thiosemicarbazone in $[\mathrm{Ag}(\mu-\mathrm{dppm}) 2(\mu-\mathrm{SR})$ $\mathrm{Ag}(\mathrm{ONO} 2)](\mathrm{NO} 3)$ dimer with a new $\{\mathrm{Ag} 2(\mu-\mathrm{P}, \mathrm{P}) 2(\mu-\mathrm{SR})\}$ core," Inorganic Chemistry Communications, vol. 10, no. 11, pp. 1307-1310, 2007.

[35] C. Pettinari, J. Ngoune, A. Marinelli, B. W. Skelton, and A. H. White, "Silver(I) methanesulfonate complexes containing diphosphine ligands: spectroscopic and structural characterization," Inorganica Chimica Acta, vol. 362, no. 9, pp. 3225-3230, 2009.
[36] S. Nawaz, A. A. Isab, K. Merz et al., "Synthesis, characterization and antimicrobial studies of mixed ligand silver(I) complexes of triphenylphosphine and heterocyclic thiones: crystal structure of bis $[\{(\mu 2$-diazinane-2-thione)(diazinane-2thione)(triphenylphosphine)silver(I) nitrate\}]," Polyhedron, vol. 30, no. 9, pp. 1502-1506, 2011.

[37] P. S. Pregosin, "31P and 13C NMR studies on metal complexes of phosphorus-donors: recognizing surprises," Coordination Chemistry Reviews, vol. 252, no. 21-22, pp. 2156-2170, 2008.

[38] H. Caldwell, S. Isseponi, P. S. Pregosin, A. Albinati, and S. Rizzato, "Reactions of $\mathrm{Ru}(\mathrm{Cp} *)$ complexes with $\mathrm{P}$ (o-tolyl) 3," Journal of Organometallic Chemistry, vol. 692, no. 19, pp. 4043-4051, 2007.

[39] M. Altaf, H. Stoeckli-Evans, A. Cuin et al., "Synthesis, crystal structures, antimicrobial, antifungal and antituberculosis activities of mixed ligand silver(I) complexes," Polyhedron, vol. 62, pp. 138-147, 2013.

[40] K. Nomiya, S. Takahashi, and R. Noguchi, "Synthesis and crystal structure of a hexanuclear silver(I) cluster [Ag(Hmna)] $6.4 \mathrm{H} 2 \mathrm{O}(\mathrm{H} 2 \mathrm{mna}=2$-mercaptonicotinic acid) and a supramolecular gold(I) complex $\mathrm{H}[\mathrm{Au}(\mathrm{Hmna}) 2]$ in the solid state, and their antimicrobial activities," Journal of the Chemical Society, Dalton Transactions, no. 13, pp. 2091-2097, 2000.

[41] A. Mital, D. Murugesan, M. Kaiser, C. Yeates, and I. H. Gilbert, "Discovery and optimisation studies of antimalarial phenotypic hits," European Journal of Medicinal Chemistry, vol. 103, pp. 530-538, 2015.

[42] V. R. Solomon, W. Haq, M. Smilkstein et al., "Synthesis and antimalarial activity of novel side chain modified antimalarial agents derived from 4-aminoquinoline," Medicinal Chemistry, vol. 4, no. 5, pp. 446-456, 2008.

[43] V. R. Solomon, W. Haq, K. Srivastava, S. K. Puri, and S. B. Katti, "Design, synthesis of 4-aminoquinoline-derived thiazolidines and their antimalarial activity and heme polymerization inhibition studies," Journal of Enzyme Inhibition and Medicinal Chemistry, vol. 28, no. 3, pp. 619-626, 2013.

[44] K. Katsuno, J. N. Burrows, K. Duncan et al., "Hit and lead criteria in drug discovery for infectious diseases of the developing world," Nature Reviews Drug Discovery, vol. 14, no. 11, pp. 751-758, 2015.

[45] B. Weniger, S. Robledo, G. J. Arango et al., "Antiprotozoal activities of Colombian plants," Journal of Ethnopharmacology, vol. 78, no. 2-3, pp. 193-200, 2001.

[46] J. Ferlay, H. R. Shin, F. Bray, D. Forman, C. Mathers, and D. M. Parkin, "Estimates of worldwide burden of cancer in 2008: GLOBOCAN 2008," International Journal of Cancer, vol. 127, no. 12, pp. 2893-2917, 2010.

[47] K. I. Deen, H. Silva, R. Deen, and P. C. Chandrasinghe, "Colorectal cancer in the young, many questions, few answers," World Journal of Gastrointestinal Oncology, vol. 8, no. 6, pp. 481-488, 2016.

[48] O. Zainal Ariffin and I. T. N. Saleha, Malaysia-National Cancer Registry Report, Malaysia Cancer Statistics-Data and Figure 2007, National Cancer Registry, Ministry of Health (Malaysia), Putrajaya, Malaysia, 2011.

[49] M. H. Redden and G. M. Fuhrman, "Neoadjuvant chemotherapy in the treatment of breast cancer," Surgical Clinics of North America, vol. 93, no. 2, pp. 493-499, 2013.

[50] N. Matsuda, X. Wang, B. Lim et al., "Safety and efficacy of panitumumab plus neoadjuvant chemotherapy in patients with primary HER2-negative inflammatory breast cancer," JAMA Oncology, 2018. 
[51] S. Crawford, "Is it time for a new paradigm for systemic cancer treatment? Lessons from a century of cancer chemotherapy," Frontiers in Pharmacology, vol. 4, p. 68, 2013.

[52] K. O. Alfarouk, C. M. Stock, S. Taylor et al., "Resistance to cancer chemotherapy: failure in drug response from ADME to P-gp," Cancer Cell International, vol. 15, no. 1, p. 71, 2015.

[53] X. Han, Y. Zhou, and W. Liu, "Precision cardio-oncology: understanding the cardiotoxicity of cancer therapy," npj Precision Oncology, vol. 1, no. 1, p. 31, 2017.

[54] M. Morris, C. Platell, K. McCaul et al., "Survival rates for stage II colon cancer patients treated with or without chemotherapy in a population-based setting," International Journal of Colorectal Disease, vol. 22, no. 8, pp. 887-895, 2007.

[55] B. Desoize, "Metals and metal compounds in cancer treatment," Anticancer Research, vol. 24, no. 3a, pp. 1529-1544, 2004.

[56] S. J. Tan, Y. K. Yan, P. P. F. Lee, and K. H. Lim, "Copper, gold and silver compounds as potential new anti-tumor metallodrugs," Future Medicinal Chemistry, vol. 2, no. 10, pp. 1591-1608, 2010.

[57] S. Shukla and A. P. Mishra, "Synthesis, structure, and anticancerous properties of silver complexes," Journal of Chemistry, vol. 2013, Article ID 527123, 6 pages, 2013.

[58] S. Wang, H. Yu, and J. K. Wickliffe, "Limitation of the MTT and XTT assays for measuring cell viability due to superoxide formation induced by nano-scale $\mathrm{TiO}_{2}$," Toxicology in Vitro, vol. 25, no. 8, pp. 2147-2151, 2011.

[59] Y. J. Wang, S. M. Zhou, G. Xu, and Y. Q. Gao, "Interference of phenylethanoid glycosides from Cistanche tubulosa with the MTT assay," Molecules, vol. 20, no. 5, pp. 8060-8071, 2015.

[60] A. van Tonder, A. M. Joubert, and A. D. Cromarty, "Limitations of the 3-(4,5-dimethylthiazol-2-yl)-2,5-diphenyl-2Htetrazolium bromide (MTT) assay when compared to three commonly used cell enumeration assays," BMC Research Notes, vol. 8, p. 47, 2015.

[61] U. Kalinowska-Lis, A. Felczak, L. Chęcińska et al., "Antibacterial activity and cytotoxicity of silver(I) complexes of pyridine and (benz)imidazole derivatives. X-ray crystal structure of $\left[\mathrm{Ag}\left(2,6-\mathrm{di}\left(\mathrm{CH}_{2} \mathrm{OH}\right)\right.\right.$ py $\left.) 2\right] \mathrm{NO}_{3}, "$ Molecules, vol. 21, no. 2, p. 87, 2016.

[62] I. Fichtner, J. Cinatl, M. Michaelis et al., "In vitro and in vivo investigations into the carbene silver acetate anticancer drug candidate SBC1," Letters in Drug Design and Discovery, vol. 9, no. 9, pp. 815-822, 2012.

[63] P. Zhang and P. J. Sadler, "Redox-active metal complexes for anticancer therapy," European Journal of Inorganic Chemistry, vol. 2017, no. 12, pp. 1541-1548, 2017.

[64] F. K. Keter, I. A. Guzei, M. Nell, W. E. van Zyl, and J. Darkwa, "Phosphinogold(I) dithiocarbamate complexes: effect of the nature of phosphine ligand on anticancer properties," Inorganic Chemistry, vol. 53, no. 4, pp. 2058-2067, 2014.

[65] M. S. A. El-Gaby, Z. H. Ismail, S. M. Abdel-Gawad, H. M. Aly, and M. M. Ghorab, "Synthesis of thiazolidine and thiophene derivatives for evaluation as anticancer agents," Phosphorus, Sulfur, and Silicon and the Related Elements, vol. 184, no. 10, pp. 2645-2654, 2009.

[66] V. Asati, D. K. Mahapatra, and S. K. Bharti, “Thiazolidine-2,4diones as multi-targeted scaffold in medicinal chemistry: potential anticancer agents," European Journal of Medicinal Chemistry, vol. 87, pp. 814-833, 2014. 

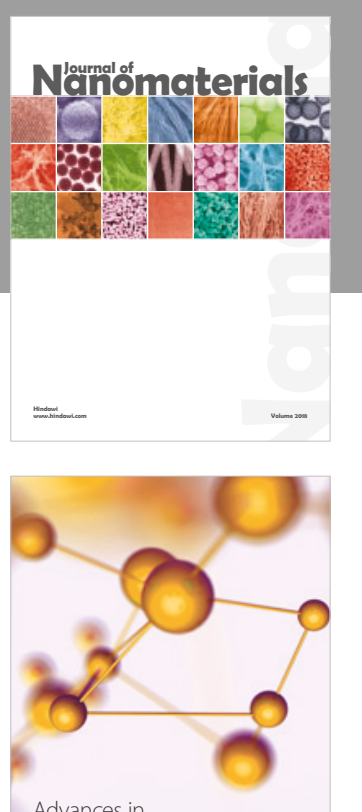

Physical Chemistry
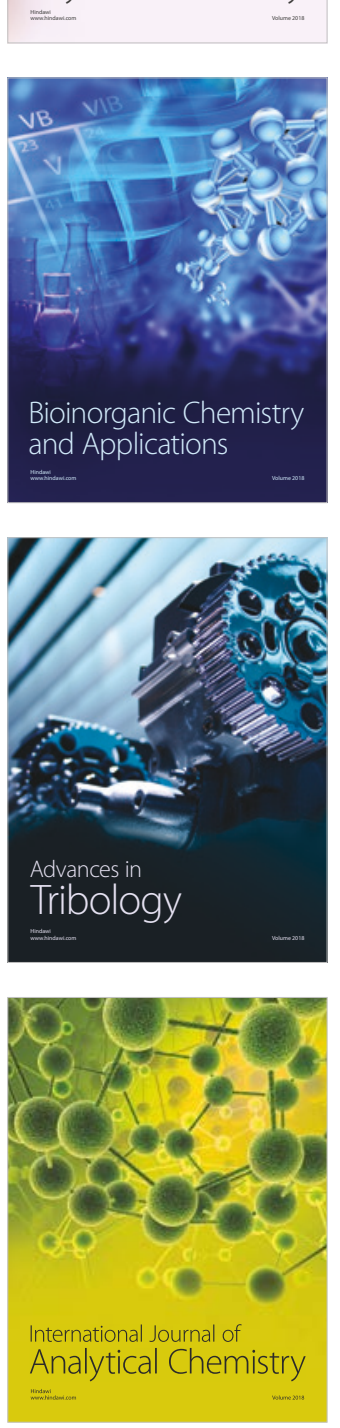

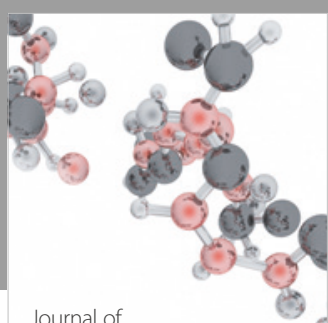

Analytical Methods

in Chemistry

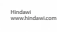

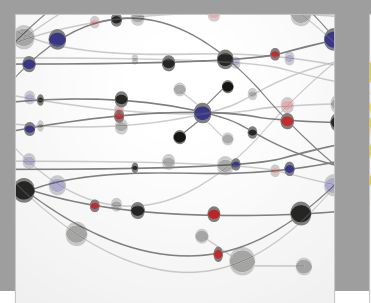

The Scientific World Journal

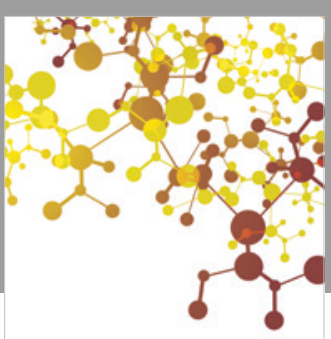

Journal of

Applied Chemistry
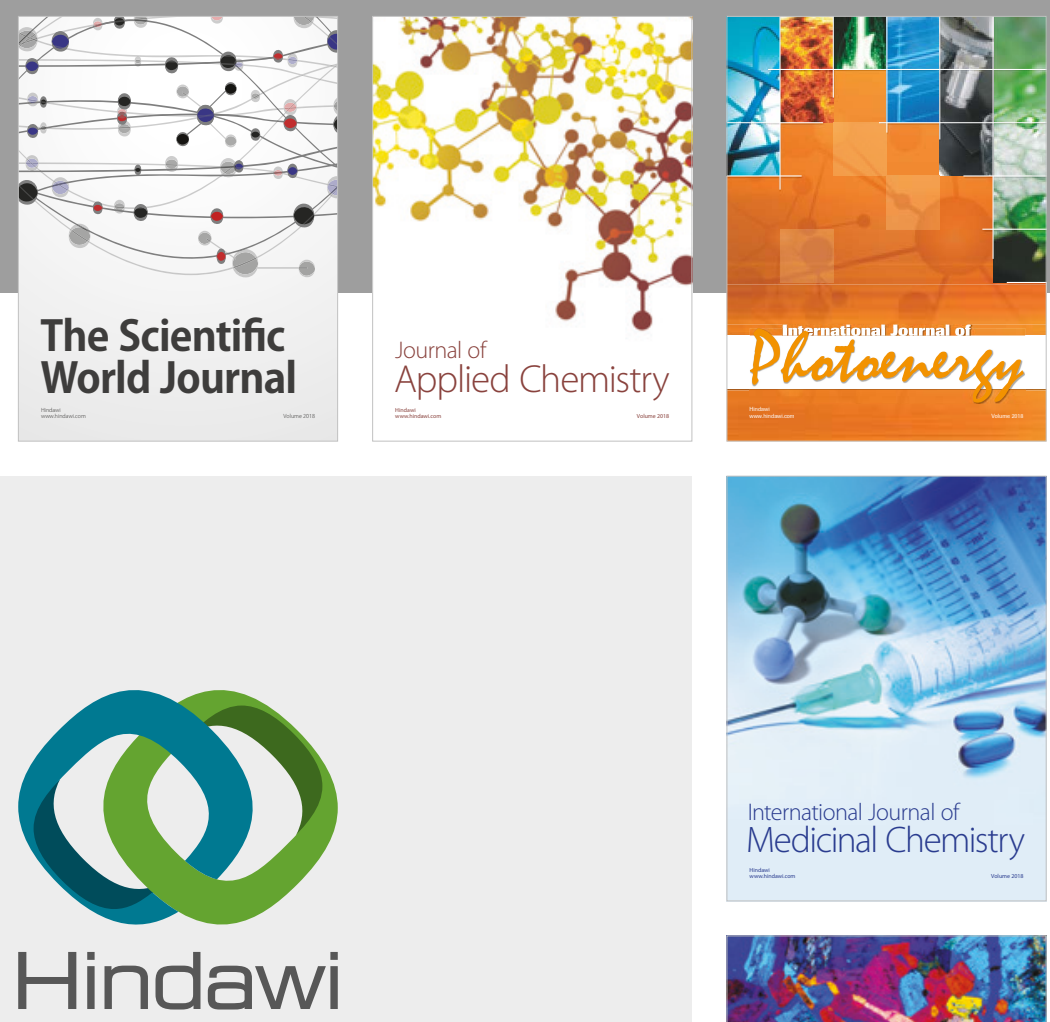

Submit your manuscripts at

www.hindawi.com
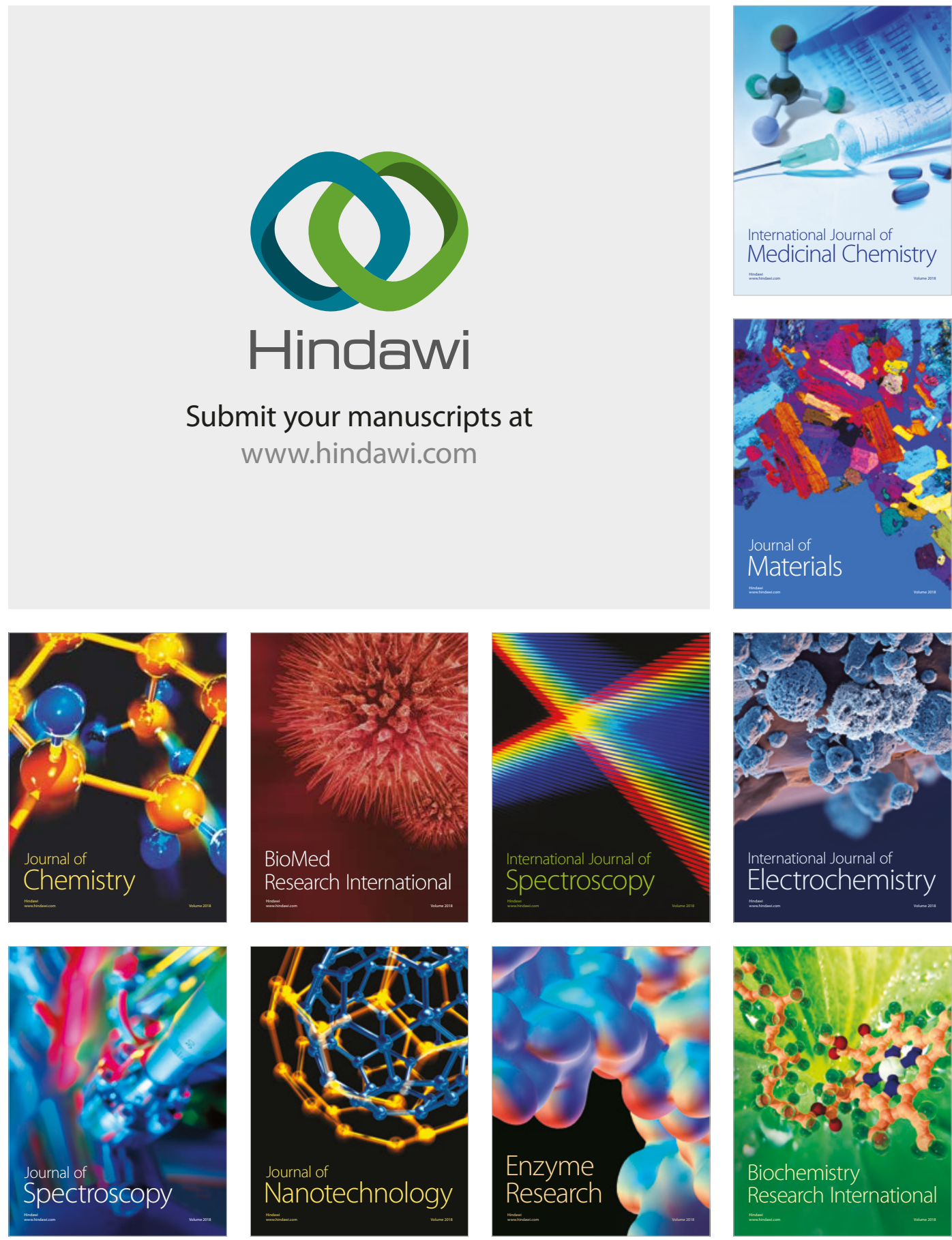
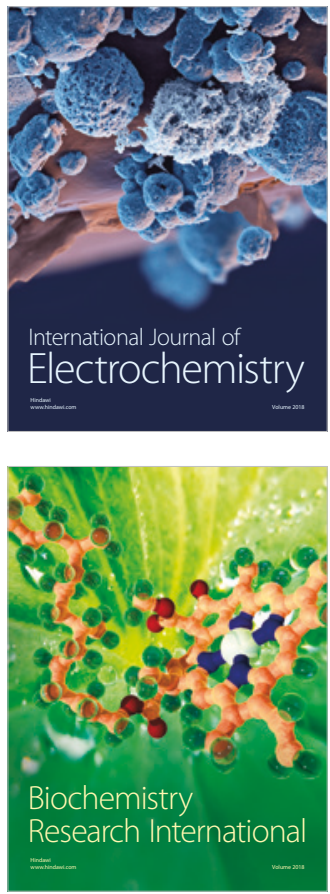